\title{
Freedom-deprived women: social representations of prison, violence, and their consequences
}

\author{
Mulheres privadas de liberdade: representações sociais de prisão, violência e suas consequências \\ Mujeres privadas de libertad: representaciones sociales de la prisión, la violencia y sus consecuencias
}

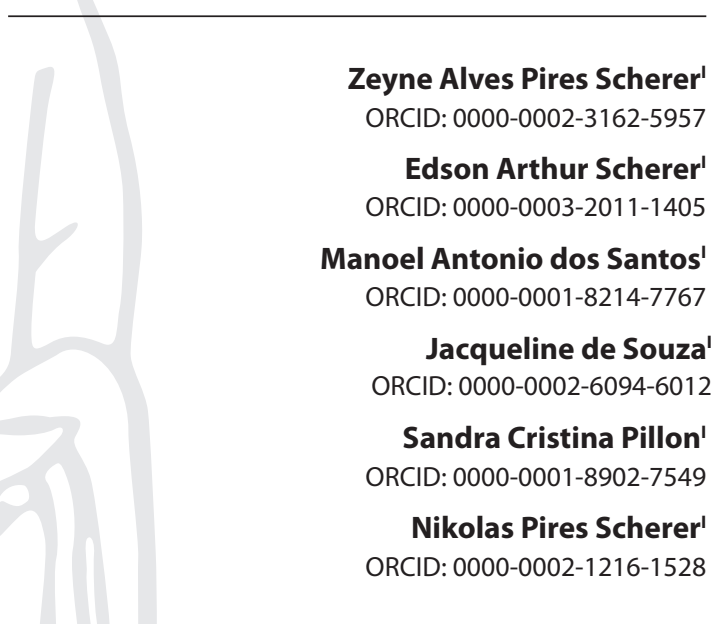

'Universidade de São Paulo. Ribeirão Preto, São Paulo, Brazil.

How to cite this article: Scherer ZAP, Scherer EA, Santos MA, Souza J, Pillon SC, Scherer NP. Freedom-deprived women: social representations of prison, violence, and their consequences. Rev Bras Enferm. 2020;73(3):e20180781. doi: http://dx.doi.org/10.1590/0034-7167-2018-0781

\section{Corresponding author:}

Zeyne Alves Pires Scherer

E-mail: scherer@eerp.usp.br

EDITOR IN CHIEF: Antonio José de Almeida Filho ASSOCIATE EDITOR: Hugo Fernandes

Submission: $10-09-2018$

Approval: 03-15-2019

\begin{abstract}
Objective: To understand the social representations that women deprived of their freedom have of imprisonment, violence, and their consequences. Method: An exploratory-descriptive qualitative study with 15 women from a female penitentiary in the State of São Paulo, Brazil. Semistructured interview was used. Data submitted to thematic content analysis and interpreted under Social Representations. Results: Categories identified: "Enclosed and abandoned in the prison environment": loss of contact with relatives, difficulties living in prison, and right to be reinserted into society. "Imprisoned in a cycle of social inequality": lack of support, access to education and employment opportunities, leading them to engage in new illicit activities and consequent imprisonment. Final considerations: The social representations of prisoners suggest that they perceive themselves to be doubly "imprisoned", either from the objective point of view, as an individual deprived of freedom; or subjective, as citizens who have their rights disrespected and their possibilities of rehabilitation limited by the prison system. Descriptors: Women; Prisons; Violence; Nursing; Violence Against Women.
\end{abstract}

\section{RESUMO}

Objetivo: Compreender as representações sociais que mulheres privadas de liberdade têm sobre prisão, violência e suas consequências. Método: Estudo qualitativo exploratóriodescritivo realizado com 15 mulheres de uma penitenciária feminina do estado de São Paulo, Brasil. Foi utilizada entrevista semiestruturada. Dados submetidos à análise de conteúdo temática e interpretados à luz das Representações Sociais. Resultados: Categorias identificadas: "Enclausuradas e abandonadas no ambiente prisional": perda de contato com familiares, dificuldades de convívio na prisão e direito de serem reinseridas na sociedade. "Aprisionadas em um ciclo de desigualdade social": falta de apoio, acesso à educação e oportunidades de emprego, levando-as ao envolvimento em novas atividades ilícitas e consequente aprisionamento. Considerações finais: As representações sociais das detentas sugerem que elas se percebem duplamente "aprisionadas", seja do ponto de vista objetivo, como indivíduo privado de liberdade; ou subjetivo, como cidadãs que têm seus direitos desrespeitados e suas possibilidades de reabilitação limitadas pelo sistema prisional. Descritores: Mulheres; Prisões; Violência; Enfermagem; Violência Contra a Mulher.

\section{RESUMEN}

Objetivo: Comprender las representaciones sociales que las mujeres privadas de su libertad tienen sobre la prisión, la violencia y sus consecuencias. Método: Estudio cualitativo exploratorio-descriptivo realizado con 15 mujeres de una cárcel femenina del Estado de São Paulo, Brasil. Se utilizó una entrevista semiestructurada. Los datos se sometieron al análisis de contenido temático y fueron interpretados a la luz de las Representaciones Sociales. Resultados: Categorías identificadas: "Enclaustradas y abandonadas en el ámbito penitenciario": pérdida de contacto con los familiares, dificultades de convivencia en la prisión y en lo que se refiere al derecho a ser reintegradas en la sociedad. "Encarceladas en un ciclo de desigualdad social": falta de apoyo, acceso a la educación y oportunidades de empleo, llevándolas a involucrarse en nuevas actividades ilícitas y por consiguiente volver a ser encarceladas. Consideraciones Finales: Las representaciones sociales de las detenidas sugieren que ellas se sienten doblemente "encarceladas", tanto desde el punto de vista objetivo, como individuo privado de su libertad, como del subjetivo, ciudadanas cuyos derechos no son respetados y sus posibilidades de rehabilitación son limitadas por el sistema penitenciario.

Descriptores: Mujeres; Cárceles; Violencia; Enfermería; Violencia Contra la Mujer. 


\section{INTRODUCTION}

Currently, the media representations of violence have massively invaded the collective imagination, exposing the population to the perverse effects of discourses that, on the pretext of fighting violent acts, have in fact contributed to spreading a generalized feeling of panic and impotence in the face of the supposed loss of control of the State against crime and delinquency. Trafficking, which puts weapons and drugs into circulation, floods the periphery of large cities, where the state is absent, and the expansion of the organized crime network is nurtured by the maintenance of illegal businesses branching out into globalized markets. One of the aggravating factors of organized crime is the enticement of economically underprivileged young people to serve the interests of their shady, highly profitable business. The lack of opportunity to enter the labor market as a citizen and equal access to cultural goods, and the universe of consumption makes the violence market a viable choice for the young population, thirsting for social recognition $^{(1-2)}$. In this adverse scenario, women have been increasingly co-opted and led to be part of this perverse reality. Once they enter the "world of crime," one of the presumed consequences after some time of exposure is imprisonment.

According to the Map of Incarceration, Brazil ranks fourth in the world rankings of the prison population and the first when compared to other South American countries ${ }^{(3)}$. When comparing different countries, Brazil has the fourth largest female prison population in the world, losing position only to the United States (211,870 women), China $(107,131)$, and Russia $(48,478)$, according to INFOPEN Women data ${ }^{(4)}$. The distribution of the prison population in the country by gender has shown a predominance of men, considering the profile of people imprisoned in the period from 2000 to 2016. In June 2016, Brazil had a population of 726,712 people in custody in the Penitentiary System, of which 42,355 were women and 665,482 were men ${ }^{(4)}$. The number of places for women in mixed, male and female penal establishments was 27,029 , with an occupancy rate of $156.7 \%$ and a deficit of 15,326 places. Between 2000 and 2016, the female prison population increased from 5,601 to 42,355, an increase of $656 \%$ over 16 years. In the same period the male prison population grew $293 \%$, jumping from 169 thousand to 655 thousand ${ }^{(4)}$.

This growing context of incarceration has led Brazilian researchers, from the 1980s to the present, to undertake efforts to analyze the meanders of the Brazilian prison system and the growth of prison population from different perspectives, in order to understand the details of this process ${ }^{(5-8)}$.

Studies on prison dynamics discuss the specificities of the female condition in prisons originally built for male imprisonment. Thus, different authors consider prisons as institutions associated with the sustenance of manly morality and sexuality, regardless of the population they serve ${ }^{(8-10)}$. This masculine logic conditions perverse administrative practices by placing women in the background, generating even more suffering for this part of the population that is still subordinated to male domination ${ }^{\left({ }^{8}\right)}$. The authors point out that, although prison is a public space, female cells can be correlated to the private sphere, remembering that the domestic environment is considered as the space par excellence of women. Public space is identified as male territory ${ }^{(8,10)}$.
Knowing the reality of prisons, or even approaching the stories of those serving prison sentences, can have an impact because it is repelled, distanced and feared by society. It causes greater impact when they are stories that have the woman as agent of violence capable of committing crimes, which contradicts the representation of the weak and sensitive woman. Given this context, we asked: What is the social representation of imprisonment, violence, and their consequences for imprisoned women?

\section{OBJECTIVE}

To understand the social representations that women deprived of their freedom have of imprisonment, violence, and their consequences.

\section{METHOD}

\section{Ethical aspects}

The research complied with the standards of the institution and Resolution No. 466/12 of the National Health Council. In compliance with ethical standards, the participants were guided about the objectives and purposes of the research and about the respect to the confidentiality of their identification. Those who agreed to participate in the study signed, in two copies, the Free and Informed Consent Form (FICF).

\section{Theoretical and methodological background}

In order to problematize the situation of women deprived of their freedom, especially in relation to the perceived consequences of imprisonment on their lives, we begin with a contextualization that shows how they are exposed to a series of factors that both victimize them and make them feel participants or accomplices of violent acts. Thus, when we consider the complex and multifactorial dimension of violence, which includes its social, cultural, and historical determinants, we use the Theory of Social Representations ${ }^{(11)}$ to support theoretical interpretations to understand socially constructed meanings about the nature of imprisonment. With this we intend to rescue the construction of the thought of a group of imprisoned women, their beliefs, values, opinions, and knowledge. The use of social representations to understand the consequences of life in prison is justified by the assertion that it is impossible to understand this experience without questioning how are the senses, values, and beliefs that organize and occupy social life, which are the content of social representations ${ }^{(12)}$. Social representations thus allow us to perceive the senses that women deprived of their freedom confer to their knowledge and practices, without leaving the prison context in the background. These representations consider both the subjective aspect (attributed sense) and the objective dimension (context) as basic components of this form of social relationship. It is possible to assume that the interaction of social representations of life in prison, the contexts of deprivation, and the violence that permeates them contribute to understand the consequences perceived by the imprisoned woman. This ends up interfering in how much the fulfillment of 
the sentence produces positive or negative effects in the future life of the inmate. Therefore, social representations, by making it possible to capture the relationships between objective and subjective aspects of imprisonment, collaborate with the definition of someone as "prisoner" (current condition) and future former prisoner in the process of social reintegration ${ }^{(12)}$.

\section{Type of study}

This is an exploratory-descriptive qualitative study ${ }^{(13)}$, with the purpose of recovering the experiences of women in situations of imprisonment.

\section{Methodological procedures}

\section{Study Scenario}

The study was developed at the Female Penitentiary of Ribeirão Preto, SP, Brazil.

\section{Data source}

Fifteen women deprived of their freedom participated in the study. The selection of the participants was random. To do so, from the official list (alphabetical order) of 310 prisoners, provided by the penitentiary, the criterion of the arithmetic progression of reason 20 was used counting from the first name of this list. The recruitment of the participants was previously performed by a professional from the penitentiary who informed them that researchers from the University of São Paulo would like to hear from them about their experiences of imprisonment. In the selection, when any of the selected women did not agree to participate in the study, women were selected in a position immediately after or before the list, respectively. The definition of this intentional sample was based, therefore, on the theoretical saturation closure technique ${ }^{(14)}$, that is, the inclusion of new participants was suspended when the data obtained were redundant or repetitive and they did not add information relevant to the understanding of the phenomenon under study.

\section{Data collection and organization}

For data collection, a semi-structured interview ${ }^{(13)}$ was used, previously elaborated by the researchers and submitted to the appreciation of three expert judges on the issue of violence and the Social Representations method. The questions contained data on the perception and consequences of imprisonment in the participants' lives. The women were interviewed by a nurse with experience in violence, doctoral level, and by a graduate student, trained to collect qualitative data. The interviews were recorded in audio and held in a reserved room, on Saturdays and at times previously scheduled according to the availability of the researchers and the institution. The time of application of each interview ranged from 20 to 45 minutes. After each interview, a field journal was written by the interviewers, recording their perception about the respondents (gestures, attitudes, and voice inflections).

\section{Data analysis}

The authors of this study were previously trained in the methods of analysis at meetings of the study group on violence, coordinated by the main investigator. Data were subjected to content analysis ${ }^{(13)}$.The interviews were transcribed literally and completely, with subsequent reading, attentive and exhaustive re-reading of the discourses to select and group the units of signification, defining them in conceptual categories according to analogic regrouping. The grouping of data into categories was performed by two researchers who later discussed the divergences found by discriminating them from a consensus. Subsequently, a third researcher also checked the grouping of the results in order to identify the mutual exclusivity of the categories generated. The results were discussed in the group of studies on violence and, finally, an articulation of the empirical material with the literature and an interpretation according to the theoretical and methodological background of Social Representations were realized ${ }^{(11-12)}$.

In order to ensure the confidentiality of the participants' identity, each one was assigned the alphabetical sequence $A, B$, $C, D, \ldots$ until the letter $P$, as the interviews took place.

Based on the statements extracted from the interviews, two categories were identified, which were defined as the central themes of the analysis: "Enclosed and abandoned in the prison environment: inside this place, we die more than live" and "Imprisoned in a cycle of social inequality: the whole society is violent." These categories were described and exemplified by the excerpts extracted from the discourses of the women interviewed.

\section{RESULTS}

The age range of the women in this study went from 21 to 74 years old, with a mean of 32 years old; 10 declared themselves unmarried and 5 married or cohabiting; 13 were from the state of São Paulo; 11 Catholic and 4 Pentecostal evangelicals; and they attended school on average for 6.5 years. They performed labor activities of low qualification and remuneration (household chores, salespersons, nursing assistant, manicure, merchant, farm worker). They lived with the family until their seclusion, with an average family income of one thousand reais.

\section{Enclosed and abandoned in the prison environment: inside this place, we die more than live}

By profiling their social representations, women have shown their difficulties of being recognized as human beings with feelings and who experience joys and sufferings. In the constellation of relationships, they establish with other people, as those who share the prison environment with, they perceive themselves treated as marginal - abject beings or social scum. Opposing this deteriorated identity attributed to them by common sense, they claim the right to be treated with respect and dignity, and to have a second chance to be reinserted into society.

I think the society out there had to see that it is not because we are here inside that we have no right to leave, to resocialize in society. Show that life is not just this world of crime here. It is not only why we are here that we are marginalized. (A) 
Inmates suffer as well. We are all the same, the same suffering. Inmates should think so. But they want to be better than the other. Hard to live here. (F)

There was an episode that happened to an inmate, in which the officer said: "Oh, I do not even want to know, you guys are crap." We can be trash to society, because in reality we are, you know? But we are human beings, too. And even garbage is recyclable, right? I think we deserve at least to be treated with dignity as a human being. $(\mathrm{J})$

The prison environment puts in intimate contact people of the most varied origins and personalities, which often makes coexistence difficult with the others imprisoned women:

You do not have room to sleep properly. You have to live with people you do not know, ignorant people. You say one thing, one does not understand, it leads to the other side. $(\mathrm{G})$

We never know who the real one is. So, we end up living with people and living their stories. $(\mathrm{O})$

Coming here is punishment, you cannot complain. I do not speak, I do not leave the cell, I keep quiet to avoid confusion, because I want to leave soon. $(\mathrm{H})$

If you are not careful, your time in prison end up being increased. You have to be quiet, pay attention to what you say and what you do. $(\mathrm{P})$

Often, the family leaves prisoners, who in turn feel a strong need and wish to maintain family bonds. In addition to valuing family bonds, they complained not only of the loss of daily contact with family members, but also of the comfort and pleasures that life outside prison can provide.

So many losses being in this place! Six months ago, I lost my mother and, after a month, my brother. All this happened to me being inside that place... it was a lesson, I will never forget this place, the things that I live, that I see... All I'm going to do out there, I'Il remember what to eat, wear, all this has value after we fall in here. Only those who come here know what this place is. (C)

I do not have a visit, I do not receive a letter, I do not leave, I have nothing. I do not even have feelings in this place. I do not have a single visit, I do not receive letters, I do not receive packages, I have nothing. (E)

I was wrong to sell drugs... we have to stay here to learn. I have a one-year-old son out there, he started walking and I did not see! (L)

My mother comes to see me every now and then, because it's difficult, it's going to be a year since l'm here and she came only twice because she cannot come. And my boy she cannot bring because she cannot walk. This is how the thing works in here, inside this place, we die more than live. $(\mathrm{J})$

We pay and we are paying a high price, which is being very far from the family. I have not seen my two daughters for a year and a half. (A)

\section{Imprisoned in a cycle of social inequality: the whole so- ciety is violent}

Women deprived of their freedom are clearly aware that they suffer from innumerable difficulties imposed on them by society, but they do not regard it as a form of violence (neglect or abandonment), but a well-deserved punishment. They represent their difficulties of social adjustment, in relation to reeducation and rehabilitation, as a result of their lack of interest, knowledge, capacity, and responsibility of the people in general. These social inequalities in turn generate barriers to access quality formal education and opportunities for better jobs. They understand that these factors, synthesized in the expression "it was due to lack of choice", led them to engage in illicit activities and, consequently, to imprisonment.

I think it's not a form of violence, but rather a lack of jobs for us. It is lack of opportunity, of jobs choices. There were times when I was unemployed, so I had to become a cleaning lady. I went to the traffic light to ask, with my children on the side... it was for lack of choice. There has to be more jobs, more opportunity for us to do something else. (N)

I think it is lack of knowledge and interest of the person, of the parents as well. It is a responsibility of the adult people. $(\mathrm{H})$

The whole society is violent, because we have education out there, but many of the people who do not have the privilege of having this education end up going to another kind of course. It is where it generates violence and damage to society. (M)

One of the most pervasive portrayals of motives for breaking the law and entering the world of crime was a moral matter: crime was practiced out of necessity.

I know I messed up. I just did not want to see my one-year-old son starving, or my mother. Because the money I made as a cleaning lady wasn't enough to support my family and me: the house rent, food; there was no way. That's when I messed up with drugs. (L)

I came here because I trafficked to get money to support my family. Before we came here, we lived with my mother's retirement. Then, in the review, it was denied. I did not know what to do, so the only way I found was trafficking. Job there was no way. People do not give you the opportunity, they look at you, they see a tattoo, they think they look like a thief, thug, and they end up saying not. (D)

Another motive alleged to flirt with the world of crime - and that is also an argument of moral character - was ambition:

I went for ambition a lot. I was enjoying more and more of what I was having and I did not see the consequences... I was seeing myself with a lot of money, car, you end up getting involved in a way that, when you see, I had an arrest warrant for me... I did not even believe. $(\mathrm{H})$

Involvement with the drug market, primarily as a user and subsequently as an agent of trafficking, is among the most prominent representations of the motivations that lead to criminal conduct. Some women, however, point out that their participation in 
trafficking had as its main objective the attempt to ensure their financial autonomy, and not so much the attempt to sustain personal use of the drug.

If it was not for violence, drug, I do not think I would be here. I was a user, I was dealing, it was a necessity. I wanted to show my brother that I could live and care for my children without having to ask him for a job. (L)

The type of social representation that appears condensed in the following excerpt is compounded by the common-sense fatalism that the child who did not have proper parental guidance or supervision "will one day become a delinquent":

You are a child. Do you have parents for what? To educate, to give affection to give you a life. But if inside your house you do not have affection, you have nothing to eat, you have no education, one day, later, you will become a delinquent. There is not only this way, there are other ways to go. I met people who live in the favela, who have starved, who have lost everything in life and today they are good people. But there are people who prefer to seek the easy way out. (M)

According to the social representations elaborated by the inmates, what would have led them to recidivism in criminal practice and, therefore, to the possibility of being caught again by law enforcement agents, was the difficulty of reinsertion in the world of labor, when they were released from the prison.

Most end up in crime out of necessity. I was already arrested, I left, and I'm back. The world outside does not give us the opportunity. (A)

Some women expressed feelings of apprehension and concern about the activity they could develop to ensure their livelihood when they finally got out of prison. In addition, it is noted that their social representations are woven based on the perception of lack of support and total indifference, disregard, and neglect of the prison system to their needs for readaptation to social life when they regain freedom.

You looking for the social [department], that in case is who is going to help us find a job, do something when you get out of here, and what do they give you? They give you some packets of trash for you to sell for a week. (E)

I used to deal with dolls when I left. They gave me some doll heads, some woolen yarn, and told me to find a way. Nobody showed me a job. I have experience in many things and they knew it. (O)

The speeches suggest that, from the perspective of those imprisoned, there is no commitment of the prison system to the "recovery" and "regenerate" the inmates, as advocated in their constitutional function. The testimonies also denounce the inexistence of consistent social reinsertion programs, limited to improvised actions, without continuity and monitoring in the first months after release. In this way, after serving their sentence, women are totally helpless in the face of the challenge of returning to social life, where they will have to face the stigma and prejudices that come on the people who are incarcerated. Without support to make this confrontation, they feel unprotected and helpless, with the aggravation that they will need to find some way of livelihood quickly.

When I left, I went to work in a supermarket. My boss found out that I was a former convict, he let me work the three months of experience and he sent me away, because he could not accept a former convict in his supermarket. So, it is hard to get out of jail and have a moral support, especially from society, because you might even have family, but if the family is poor and cannot help you, what are you going to do? Will you stay indoors? It's difficult. (M)

The huge difficulty of (re)joining the job can be due to both the stigma of former prisoners and the low professional qualifications. In addition, there are conflicts related to the family, which by then have already reorganized and somehow adapted to the absence of the woman who was held for a long time in prison. Overcoming the obstacles found in the path of psychosocial readjustment is an imperative need to ensure the prevention of criminal recidivism. When unfavorable factors weigh more heavily on the balance, the cycle of institutional violence is perpetuated. Women become eternal hostages, imprisoned in an infernal cycle of social inequality.

In this context, prison becomes a place of torture and suffering, a dehumanized and dehumanizing institution that depersonalizes the imprisoned woman and imposes its violence either explicitly or implicitly and silently through the printing of identity marks. It is a state apparatus that excludes those already excluded and that performs and reinforces the classic division of tasks between men and women, as well as the sexualization of jobs. In this section, one participant reported the differences between the forms of treatment that men and women receive in the mixed prison.

The companies that act inside the men's prison give work to the inmate and when he leaves, they give work outside, if he wants. Because my brother worked at a business in a city nearby. The woman does not have it. You look for an NGO on the internet about work to help the inmate after he leaves, to resocialize. For man you find many, everywhere, and for woman you find one, in Campinas, that is the only NGO that exists. So, it's hard. You try to change your life, not everyone helps you. (B)

\section{DISCUSSION}

Before seeing and hearing people, judgments are made, classifications and images are created. In the case of the imprisoned woman, labels are used to identify her, impregnated with assumptions and prejudices. It is inserted in a single category: perpetrator of violence (crimes, trafficking, theft, among others). Society prejudges them based on rumors or stereotypes of the media, and with that denigrate their individuality, their uniqueness.

In this way, entering the prison world brings the representation of the imprisoned as dangerous people and therefore they must remain distant. The transformation of something unfamiliar into something familiar is the reason for the formation of social representations. The familiar is what is known, common sense, safe from any risk, friction or conflict, confirming beliefs, reinforcing tradition. The unfamiliar is what causes conflict, it is the unknown ${ }^{(11)}$. Listening to these women facilitated familiarization with what was unfamiliar. 
There was rapprochement with their stories of violence perpetrated and suffered outside and inside prison. Facts or beliefs transmitted over time and which are not always "what is seen", because they go unnoticed by the scope of the social imaginary. It approached the common-sense knowledge, socially constructed to give meaning to the reality of everyday life in the prison environment.

The first experiences in a prison institution cause the inmates a real impact, an experience marked by the anguish of not knowing what to do in that place. People deprived of their freedom need to adapt to a different way of life, which ends up acting as a provoking element of revolt, and it can be translated into a negative factor for their future social reinsertion ${ }^{(5,8-10)}$.

It was possible to perceive that stigma and oppression also accompany the daily life of women deprived of their freedom. Once incarcerated, women can suffer a series of punishments from staying in unsuitable places, such as undergoing treatments that are not suited to their needs. When a person enters prison abruptly, they lose their identity and humanity. They are banned from their personal referential and excluded in a new category, that of incarcerated. They collect their belongings in order to maintain prison security. One must then adapt and anchor the unknown in existing representations ${ }^{(7-11)}$. For women, this process is more devastating, as she ends up losing several references, she stops being mother, daughter and feminine, compromising her identity and autonomy. They are stigmatized by their own family and friends, because in committing crimes they break not only the established legal order, but above all the social morality in force ${ }^{(10)}$.

The distancing of the family is one of the most negative aspects present in the lives of women who are prisoners ${ }^{(15-16)}$. In women's discourses, perceptions of withdrawal conditions may be noted as one of the most painful aspects of incarceration.

There is a lack of a more careful look at women deprived of freedom, and the expansion of actions aimed at ensuring better living conditions in and out of prisons. There is a need for comprehensive female health care strategies, greater inclusion in the labor market, promotion of educational activities, consolidation of social assistance actions, and greater involvement of social movements in actions in women's prisons ${ }^{(7,9)}$. The creation and implementation of measures to support socialization paths is a growing challenge. The necessary conditions for a return to life in freedom are almost non-existent, as public policies are few to deal with the issue effectively ${ }^{(8,15)}$.

Research results on prisoners' perceptions of jail and deprivation of freedom have revealed that inmates find it difficult to remain in prison and suffer in advance from out-of-prison life prospects. So, they do not imagine a hopeful future, but a new battle for survival. They believe that the former inmate, even while serving his sentence in full, will suffer stigmatization for the rest of his life and will hardly be able to get a job or a lawful way to keep himself(6). As for women who leave the prison, those with the greatest difficulty are those with less schooling and without a qualified profession ${ }^{(8-10)}$.

Instability and lack of employment or occupation, even if informal, along with low schooling, and the need to provide for family support are factors that influence individuals to seek immediate and criminal attitudes ${ }^{(6,9)}$. As a result, social or resocialization programs seek alternatives to try to remedy the failures and difficulties of the prison system and to collaborate with the reintegration of individuals in society, giving continuity to the work of former prison inmates ${ }^{(6,9,17)}$.

Corroborating with the findings of the present study, the results of a study pointed out that the main distress related to leaving the prison was the lack of employment that could possibly occur due to a flawed and prejudiced social organization ${ }^{(18)}$. The main difficulties of reintegration were related to work and income, social interaction, and family relationship. As factors that mark the trajectory of these subjects emerge the issues related to themselves, that is, personal conflicts, traumas, feelings of failure, rejection and abandonment, caused by aggressions, humiliations inside or still outside prison ${ }^{(15,17)}$.

The projects with egresses of the prison system, therefore, are active in the process of shutting down the system and, sometimes, in the form of vocational courses. However, for a satisfactory social reintegration it would be necessary to have a continuity in the labor relations started in prisons for an extended period, outside the prison. Such conduct would contribute to reducing criminal recidivism by offering real opportunities to this population ${ }^{(9,17)}$. Cases of criminal recidivism, although less frequent among women, stem from a scarce labor market and lack of measures to accommodate such people upon their release from prison ${ }^{(17)}$. Lack of employment is, therefore, a current political-economic reality, which can be a determinant of social exclusion for the population within or outside the prison system.

It should be remembered that in society there is still a marked inequality between men and women. The policies of women's autonomy, as a principle that generates policies and actions from the public power, are proposals for society reaffirmed by the 3rd National Conference on Policies for Women. Economic autonomy and equality between women and men in the labor world are based on specific actions aimed at eliminating the unequal sexual division of labor, with an emphasis on eradicating poverty and ensuring women's participation in Brazil's development ${ }^{(18)}$. In the case of prisons and life after prison, there are evident differences related to gender ${ }^{(10)}$.

Although prison has the function of resocializing, it can end up marginalizing and worsening the lives of those who are there ${ }^{(18)}$. This is one of the elements we can call the cycle of social inequality. It begins with the motivation (for example, the lack of training and the opportunity to work) of the practice of an offense that culminated in incarceration. Subsequently, the release of the prison and the expectation of reinsertion in society, when not met, may lead to a new exclusion and, to survive, new involvement in crime (recidivism), and new prison imprisonment. And so, the cycle tends to repeat itself.

Another important issue described in studies with women deprived of their freedom refers to the treatment of substance abuse or dependence. Investing in the provision of treatments during and after release may help prevent these women from relapsing and following further treatments. In these treatments, it is of crucial importance to focus the victimization history of the participants. Since these have often been victims of physical, psychological, and sexual abuse, which corroborates their involvement in criminal activities, in addition to placing them in vulnerability to re-victimization. Creating workplaces and recovery homes that continue the treatment program to prevent relapses can help defend the human rights of this group of women and achieve social justice ${ }^{(19-20)}$. 


\section{Study limitations}

This research has significant importance, as the thematic and participants, in respect to the context of their production. It is possible to point out as a limitation of this study the fact of having used only one technique of data collection. The specificity of the penitentiary, the availability of access to women deprived of freedom to perform or apply other methods and techniques of data collection, allowing a triangulation of data, have been configured as a limit that can be overcome in other prospective studies. However, the depth, breadth, and diversity of the data found, through the opportunity to give voice and listen to women in interviews, in addition, the use of the social representations that founded the inquiries of the present study, ended up reducing the consequences of this limit in the research. Another limitation refers to the fact that it was carried out in a Brazilian penal institution, which does not allow generalizations regarding the topic addressed in other regions.

\section{Contributions to the area of nursing, health or public policy}

The knowledge made possible in this study contributes as a basis for the understanding of the reality of women regarding the aspects related to their experience in the prison and consequences in their lives after leaving the prison regimen, as they were offered the opportunity to speak, to express their concerns, and feelings.

The results found broaden the understanding of the problems faced by these people, pointing to a necessary articulation of the attention to health care and to the integrality of care in an intersectoral and interdisciplinary perspective, to a greater resolution of the needs of this population. Additionally to the knowledge of references in the legal, police, social, psychological, informal support networks and non-governmental organizations, it is a source of information to implement proper and extended care strategies for people who are in this situation of vulnerability.

Health services can also use the findings of this study in training and formative processes in order to counteract the tendency towards exclusion and stigmatization of people deprived of their freedom, both institutionalized and after leaving the system, making, many times, services inaccessible to this population.

\section{FINAL CONSIDERATIONS}

Prison, understood as the representation of a place of reproduction of social exclusion, shelters not only a multiplicity of violent acts, but people with different histories of life and conflicts. This situation prompts questions about the quality of life perspective and the interpersonal relationships of imprisoned women, and what to do to improve them.

The social representations of prisoners suggest that they perceive themselves to be doubly "imprisoned", either from the objective point of view, as an individual deprived of freedom; or subjective, as citizens who have their rights disrespected and their possibilities of rehabilitation limited by the prison system. Thus, when women enter the prison, they realize that they will not only be deprived of their freedom, but also of leading their own lives. They must then adapt and anchor the unknown in existing representations. These beliefs and values that guide their behavior constitute representations anchored in psychological explanations and microsocial interactions, which also occur in the family relationships scope.

The way these women experience violence in their homes and in their social context can generate naturalization and the adoption of violent attitudes in their relationships. They acquire violence as conduct and as the value of life without questioning and, consequently, reproduce it in other spaces.

Instead of offering healthy spaces and professional programs to promote recovery, family rapprochement, and social reintegration of women, the practices of domination/submission, discrimination, and gender violence that are evident in society end up being repeated within prisons.

It is necessary to reflect on health work (including nursing) in the population of freedom-deprived women, as well as on the planning and implementation of public policies, since the reality of this population is influenced by sociocultural contexts. Such policies should contribute to the reduction of inequalities and the establishment of universal, integral, and equitable care as recommended by the Unified Health System (SUS).

In summary, this study contributes to the advancement of knowledge and it indicates the need to institute a process of continuous evaluation of the services offered and the accomplishment of new research with populations of prison institutions, among which those that seek to establish strategies for the reintegration of these women in society and the breaking of paradigms related to them. In addition, in order to complement, we suggest studies that also have professionals and family (or visitors) as subjects.

\section{FUNDING}

The present study was supported by the Foundation for Research Support of the State of São Paulo - FAPESP (Regular Project 2007/07052-5).

\section{REFERENCES}

1. Gentilli RML, Trugilho SM. Violência e a destrutividade da sociedade do capital: consequências para as políticas públicas. Rev Polít Públicas[Internet]. 2014[cited 2018 Aug 15];18(2):523-34. Available from: http://www.periodicoseletronicos.ufma.br/índex.php/rppublica/article/download/../3944

2. Lima RS, Bueno S, Mingardi G. Estado, polícias e segurança pública no Brasil. Rev Direito GV[Internet]. 2016[cited 2018 Aug 15];12(1):49-85. Available from: http://www.scielo.br/pdf/rdgv/v12n1/1808-2432-rdgv-12-1-0049.pdf

3. Presidência da República (BR). Secretaria Geral. Mapa do encarceramento: os jovens do Brasil [Internet]. 2014. [cited 2018 Jul 07]. 112 p. Available from: http://juventude.gov.br/articles/0009/3230/mapa-encarceramento-jovens.pdf 
4. Ministério da Justiça (BR). Departamento Penitenciário Nacional. Levantamento Nacional de Informações Penitenciárias (Infopen Mulheres): Junho 2016. 2a edição. Brasília (DF)[Internet]. 2018[cited 2018 Jul 07]. Available from: http://depen.gov.br/DEPEN/depen/sisdepen/infopenmulheres/infopenmulheres_arte_07-03-18.pdf

5. Paixão GPN, Pereira A, Gomes NP, Campos LM, Cruz MA, Santos PF. The experience of the preventive detention due to conjugal violence: men's speech. Texto Contexto Enferm[Internet]. 2018[cited 2018 Aug 14];27(2):e3820016. Available from: http://www.scielo.br/pdf/tce/ v27n2/0104-0707-tce-27-02-e3820016.pdf

6. 6. Soares Filho MM, Bueno PMMG. Demography, vulnerabilities and right to health to Brazilian prison population. Cien Saude Colet[Internet]. 2016[cited 2018 Aug 14]; 21(7):1999-2010. Available from: http://www.scielo.br/pdf/csc/v21n7/1413-8123-csc-21-07-1999.pdf

7. Lermen HS, Gil BL, Cúnico SD, Jesus LO. Saúde no cárcere: análise das políticas sociais de saúde voltadas à população prisional brasileira. Physis[Internet]. 2015[cited 2018 Aug 14]; 25(3):905-924. Available from: http://www.scielo.br/pdf/physis/v25n3/0103-7331physis-25-03-00905.pdf

8. Muniz CR, Leugi GB, Alves AM. Mulheres no sistema prisional: Por que e como compreender suas histórias? RP3-Rev Pesqui Pol Públicas[Internet]. 2017[cited 2018 Aug 15];(2):1-22. Available from: http://periodicos.unb.br/index.php/rp3/article/view/26945/20238

9. Cortina MOC. Mulheres e tráfico de drogas: aprisionamento e criminologia feminista. Rev Estud Fem[Internet]. 2015[cited 2018 Jun 13];23(3):761-78. Available from: http://www.scielo.br/pdf/ref/v23n3/0104-026X-ref-23-03-00761.pdf

10. Souza LAF. As contradições do confinamento no Brasil uma breve revisão da bibliografia sobre encarceramento de mulheres. Soc Debate[Internet]. 2016[cited 2018 Dec 11];22(2):127-156. Available from: http://www.rle.ucpel.tche.br/index.php/rsd/article/view/1448/949

11. Moscovici, S. $\neg$ Representações sociais: investigação em psicologia social. 9a ed. Petrópolis (RJ): Vozes; 2012.

12. Porto MSG. A violência, entre práticas e representações sociais: uma trajetória de pesquisa. Soc Estado[Internet]. 2015 [cited 2018 Aug 16];30(1):19-37. http://www.scielo.br/pdf/se/v30n1/0102-6992-se-30-01-00019.pdf

13. Minayo MCS. Introdução à metodologia das ciências sociais. O desafio do conhecimento: pesquisa qualitativa em saúde. $14^{a}$ ed. São Paulo (SP): Hucitec; 2014.

14. Fontanella BJB, Luchesi BM, Saidel MGB, Ricas J, Turato ER, Melo DG. Amostragem em pesquisas qualitativas: proposta de procedimentos para constatar saturação teórica. Cad Saúde Pública[Internet]. 2011 [cited 2018 Dec 11]; 27(2):389-94. Available from: http://www.scielo.br/ $\mathrm{pdf} / \mathrm{csp} / \mathrm{v} 27 \mathrm{n} 2 / 20 . \mathrm{pdf}$

15. Pereira EL. Famílias de mulheres presas, promoção da saúde e acesso às políticas sociais no Distrito Federal, Brasil. Cienc Saude Colet [Internet]. 2016[cited 2018 Aug 16];21(7):2123-34. Available from: http://www.scielo.br/pdf/csc/v21n7/1413-8123-csc-21-07-2123.pdf

16. De Claire K, Dixon L. The effects of prison visits from family members on prisoners' well-being, prison rule breaking, and recidivism: a review of research since 1991. Trauma Violence Abuse[Internet]. 2017[cited 2018 Jun 13];18(2):185-99. Available from: https://journals.sagepub. com/doi/pdf/10.1177/1524838015603209

17. Ribeiro F. A reinserção social da ex-presidiária no mercado de trabalho. Revice: Rev Ciên Estado[Internet]. 2017[cited 2018 Jun 13];2(1):35779. Available from: https://seer.ufmg.br/index.php/revice/article/view/6355/4822

18. Presidência da República (BR). Secretaria de Políticas para as Mulheres. Plano Nacional de Políticas para as Mulheres 2013-2015. Brasília (DF): Secretaria de Políticas para as Mulheres[Internet]. 2013[cited 2018 Jul 07]. Available from: http://www.spm.gov.br/assuntos/pnpm/ publicacoes/pnpm-2013-2015-em-22ago13.pdf.

19. Baltieri DA. Predictors of drug use in prison among women convicted of violent crimes. Crim Behav Ment Health[Internet]. 2014 [cited 2018 Jun 13];24(2):113-28. Available from: https://onlinelibrary.wiley.com/doi/epdf/10.1002/cbm.1883

20. Mejía B, Zea P, Romero M, Saldívar G. Traumatic experiences and re-victimization of female inmates undergoing treatment for substance abuse. Subst Abuse Treat Prev Policy[Internet]. 2015[cited 2018 Jul 07];10(5):1-8. Available from: https://www.ncbi.nlm.nih.gov/pmc/ articles/PMC4429492/pdf/13011_2014_Article_327.pdf 